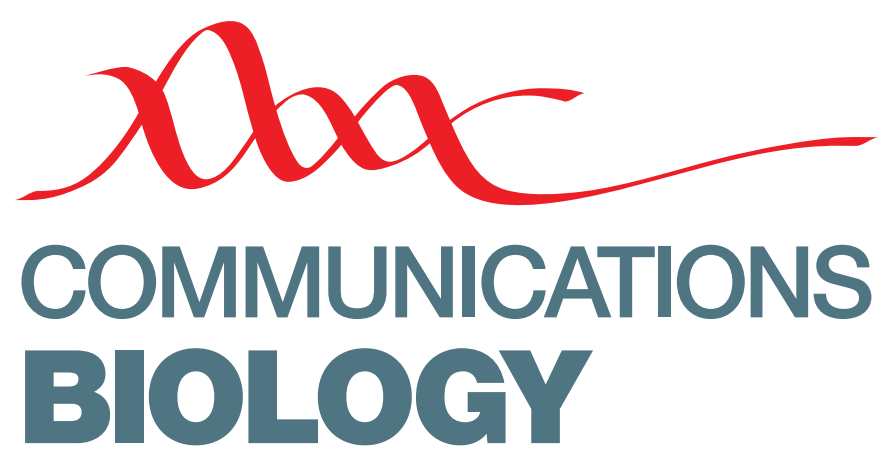

Check for updates

https://doi.org/10.1038/s42003-020-01238-z OPEN

\title{
Author Correction: Single-cell analysis of EphA clustering phenotypes to probe cancer cell heterogeneity
}

Andrea Ravasio, Myint Z. Myaing, Shumei Chia, Aditya Arora, Aneesh Sathe, Elaine Yiqun Cao, Cristina Bertocchi (D), Ankur Sharma (D), Bakya Arasi, Vin Yee Chung (D), Adrianne C. Green, Tuan Zea Tan (D), Zhongwen Chen (1D, Hui Ting Ong, N. Gopalakrishna lyer, Ruby YunJu Huang, Ramanuj DasGupta (1), Jay T. Groves \& Virgile Viasnoff(D)

Correction to: Communications Biology https://doi.org/10.1038/s42003-020-01136-4, published online 6 August 2020.

The original version of this Article contained an error in the affiliation of the author Tuan Zea Tan, which was incorrectly given as National University Health System, Singapore, Singapore. This has now been corrected to Cancer Science Institute of Singapore, National University of Singapore, Singapore in both the PDF and HTML versions of the Article.

Published online: 07 September 2020

\footnotetext{
(c) (i) Open Access This article is licensed under a Creative Commons Attribution 4.0 International License, which permits use, sharing, adaptation, distribution and reproduction in any medium or format, as long as you give appropriate credit to the original author(s) and the source, provide a link to the Creative Commons license, and indicate if changes were made. The images or other third party material in this article are included in the article's Creative Commons license, unless indicated otherwise in a credit line to the material. If material is not included in the article's Creative Commons license and your intended use is not permitted by statutory regulation or exceeds the permitted use, you will need to obtain permission directly from the copyright holder. To view a copy of this license, visit http://creativecommons.org/licenses/by/4.0/.
}

(C) The Author(s) 2020 